\title{
Reduced T-cell repertoire restrictions in abatacept-treated rheumatoid arthritis patients
}

\author{
Luisa Imberti ${ }^{1 *}$, Mirko Scarsi ${ }^{2}$, Cinzia Zanotti ${ }^{1}$, Marco Chiarini ${ }^{1}$, Diego Bertoli ${ }^{1}$, Angela Tincani ${ }^{2}$ and Paolo Airò ${ }^{2}$
}

\begin{abstract}
Background: $C D 28^{\text {neg }} T$ cells, which display functional characteristic of oligoclonally expanded cytotoxic memory $T$ lymphocytes, are believed to be pathologically relevant in rheumatoid arthritis manifestation. The CD28 co-stimulation blockade by abatacept can prevent the generation of $\mathrm{CD} 28^{\text {neg }}$ T-cell populations in these patients.

Methods: Samples were obtained before and after 12 months of abatacept therapy. T-cell phenotype and T-cell receptor diversity were evaluated by flow cytometry and complementarity-determining region-3 spectratyping, respectively, while telomerase reverse-transcriptase gene level was measured by real-time PCR.

Results: Abatacept induces a decrease of the percentage and number of $C D 4^{+} C D 28^{\text {neg }} T$ cells and a reduction of T-cell repertoire restrictions; these features are directly correlated. Thymic output and telomerase activity are not modified by the therapy.

Conclusions: Abatacept-induced decrease of peripheral T-cell repertoire restrictions can be due to a reduced generation of senescent, chronically stimulated $\mathrm{CD} 4^{+} \mathrm{CD} 28^{\text {neg }} T$ cells.
\end{abstract}

Keywords: Abatacept, Rheumatoid arthritis, T-cell repertoire

\section{Introduction}

Several changes of the T-cell compartment have been described in rheumatoid arthritis (RA) patients, which include, in some patients, an increased number of $\mathrm{T}$ cells lacking the CD28 costimulatory molecule, which are clonally expanded [1]. The emergence of $\mathrm{CD} 28^{\text {neg }} \mathrm{T}$ cells has been attributed to repeated antigenic stimulation induced by chronic inflammation or latent infections, especially by cytomegalovirus $[2,3]$. These clonal $\mathrm{T}$ lymphocytes, which display functional characteristic of cytotoxic memory $\mathrm{T}$ cells and are resistant to apoptosis, are believed to be pathologically relevant in RA development [4], and accordingly, their increase has been related to worse prognosis and extra-articular manifestations [5].

Abatacept (ABA) is a fusion protein (CTLA4-Ig) that has proven useful in the treatment of RA; its CTLA4 portion binds $\mathrm{CD} 80$ and $\mathrm{CD} 86$, the $\mathrm{CD} 28$ ligands, on antigen-presenting cells, and competing with the engagement of CD28 on T cells, the drug influences the subsequent T-cell activation [6]. Initial studies, performed in

\footnotetext{
* Correspondence: limberti@yahoo.it

${ }^{1}$ Centro Ricerca Emato-oncologica AlL (CREA), Diagnostics Department,

Spedali Civili of Brescia, p.le Spedali Civili di Brescia, 1, 25123 Brescia, Italy

Full list of author information is available at the end of the article
}

mice treated with CTLA4-Ig, showed that the treatment resulted in an inhibition of memory response and in a decrease of effector/memory populations [7]. In RA patients, ABA induces a significant down-regulation of T-cell effector subsets including Th1, Th2 and Th17 populations [8]. Furthermore, in treated patients, we have demonstrated a reduction of circulating $\mathrm{CD} 44^{+} \mathrm{CD} 28^{\text {neg }}$ and $\mathrm{CD} 8^{+} \mathrm{CD} 28^{\text {neg }} \mathrm{T}$ cells, which was correlated with an improvement of RA disease activity, suggesting that the co-stimulation blockade can prevent the generation of CD28 $8^{\text {neg }}$ T-cell populations $[9,10]$.

Since CD $28^{\text {neg }} \mathrm{T}$ cells are oligoclonally expanded lymphocytes [1], here we investigated whether their decrease during $\mathrm{ABA}$ treatment was accompanied by a reduction of T-cell repertoire restrictions. Moreover, we studied whether thymic output and apoptosis modifications were involved in these changes. For this latter purpose, since telomerase reverse transcriptase (TERT) insufficiency resulting in excessive $\mathrm{T}$-cell apoptosis [11] has been described in RA patients, we evaluated TERT activity before and after therapy with ABA. 


\section{Patients and methods Patients}

From March 2008 to December 2011, 44 consecutive RA patients treated with intravenous $A B A$ for at least 12 months were enrolled (Table 1 ).

The study was approved by the Spedali Civili of Brescia Ethical Committee (approval n. 863/fg), and patients' written consent, according to the Declaration of Helsinki, was obtained. Patient clinical evaluation followed the Disease Activity Score 28, based on C-reactive protein (DAS28-CRP) [11,12]. Blood samples were obtained at the start of ABA treatment (T0) and after 12 months of therapy (T12). Results were compared with those of 16 age- (median: 49 years, interquartile range (IQR): 39-53), and gender-matched healthy controls $(\mathrm{HC})$, which were recruited among laboratory personnel.

T-cell subset identification, TCR spectratyping analysis, and TERT quantification

T-cell subset quantification was performed by flow cytometry as previously described [9]; recent T emigrants (RTE) and highly antigen-experienced $\mathrm{T}$ cells were lymphocytes with $\mathrm{CD}^{+}{ }^{+} \mathrm{CD} 45 \mathrm{RA}^{+} \mathrm{CD} 31^{+}$and $\mathrm{CD}^{+}{ }^{+} \mathrm{CD} 45 \mathrm{RA}^{+} \mathrm{CCR} 7^{-}$ phenotypes.
T-cell receptor (TCR) repertoire was analyzed by complementarity-determining region-3 (CDR3) spectratyping after TCR beta variable (TCRBV) gene multiplex PCRs that allow the detection of 23 functional TCRBV families starting from $500 \mathrm{ng}$ of total RNA extracted from at least $2 \times 10^{6}$ peripheral blood mononuclear cells (PBMC) $[13,14]$. The length distribution of fluorescentlabelled PCR products was analyzed on an ABI 3130 analyzer (Applied Biosystems). Distribution of fragment lengths, number of detectable peaks per TCRBV element, and area under the curve were calculated by Peak Scanner software version 1.0 (Applied Biosystems). Data were analyzed and reported in three different ways; in the first two, TCRBV repertoires were globally analyzed while in the third, TCRBV perturbations were evaluated at the single patient level. Therefore, proportions of TCRBV families of all patients were grouped depending to the "normal" ( $\geq 7$ peaks, Gaussian distribution), "shifted" ( $\geq 7$ peaks, deviation from Gaussian distribution), "restricted" ( $<7$ peaks prominent deviation from Gaussian distribution), "mono/oligoclonal" (1 or 2 dominant peaks) distribution of the CDR3 region [15]. TCRBV perturbations were also evaluated with the generalized Hamming distance method [14] by "subtracting" from the CDR3

Table 1 Main clinical features of enrolled RA patients

\begin{tabular}{|c|c|c|c|}
\hline & $\begin{array}{l}\text { Total cohort of patients } \\
(n=44)\end{array}$ & $\begin{array}{l}\text { RA patients evaluated for TCRBV } \\
\text { repertoire and } T E R T^{\mathrm{b}}(\mathrm{n}=17)\end{array}$ & $\mathrm{p}$ \\
\hline Sex (male/female) & $6 / 38$ & $4 / 13$ & 0.300 \\
\hline Age, years (range) & $54(47-60)$ & $57(48-60)$ & 0.412 \\
\hline Rheumatoid factor positivity & $33(75 \%)$ & $12(70 \%)$ & 0.979 \\
\hline AntiCCP ${ }^{c}$ positivity & $36(82 \%)$ & $15(88 \%)$ & 0.825 \\
\hline Disease duration, years (range) & $8(4-13)$ & $4(2-7)$ & 0.001 \\
\hline Smokers & $14(32 \%)$ & $7(41 \%)$ & 0.697 \\
\hline \multicolumn{4}{|l|}{ Comorbidities: } \\
\hline Arterial hypertension & 17 & 4 & 0.416 \\
\hline Diabetes mellitus & 4 & 1 & 0.223 \\
\hline Cardio-vascular events & 4 & 0 & 0.478 \\
\hline Number of previous DMARDs ${ }^{d}$ & $3(2-5)$ & $2(2-3)$ & 0.001 \\
\hline \multicolumn{4}{|l|}{ Previous biological agents: } \\
\hline Infliximab & 21 & 5 & 0.313 \\
\hline Etanercept & 27 & 8 & 0.256 \\
\hline Adalimumab & 28 & 9 & 0.635 \\
\hline Rituximab & 9 & 1 & 0.321 \\
\hline Tocilizumab & 4 & 3 & 0.623 \\
\hline Anakinra & 6 & 2 & 0.999 \\
\hline DAS28-CRP at baseline (range) & $5.10(4.40-5.97)$ & $5.06(4.41-5.46)$ & 0.185 \\
\hline Median dosage of methotrexate at baseline (range) & $12.5(6.25-15)$ & $15(10-15)$ & 0.042 \\
\hline Median number of DMARDs at baseline (range) & $1(1-1)$ & $1(1-1)$ & 0.022 \\
\hline
\end{tabular}

${ }^{\mathrm{a}}$ TCRBV: T-cell receptor variable beta; ${ }^{\mathrm{b}}$ TERT: telomerase reverse transcriptase; ${ }^{\mathrm{C}}$ Anti-CCP: anti-cyclic citrullinated peptide antibodies; ${ }^{\mathrm{d}}$ DMARDs: disease modifying anti-rheumatic drugs. 
length distribution of each TCRBV of a patient, the average Gaussian-like CDR3 length distribution obtained by analyzing the TCR repertoire of a "reference group" composed of $8 \mathrm{HC}$ and then by calculating the mean percentage of restrictions. Finally, for each patient, each TCRBV perturbation observed at $\mathrm{T} 0$ was subtracted from that found at T12.

TERT was measured by real-time PCR in PBMC, stimulated for 4 days in 24-well plate coated overnight with $1 \mu \mathrm{l} / \mathrm{ml}$ of anti-CD3 monoclonal antibody diluted in PBS. Primers and probes were from Applied Biosystems (TERT: Hs00972656_m1, GUSB:Hs99999908_m1); beta-D-glucuronidase were used as housekeeping gene and pooled cells of $10 \mathrm{HC}$ as calibrator. Results were calculated with the $\Delta \Delta \mathrm{Ct}$ method and reported as normalization ratio (NR).

\section{Statistical analysis}

Data were expressed as median and IQR. The comparison between quantitative variables describing cell subpopulations in different groups was analyzed with the Mann-Whitney test, while the Wilcoxon signed-rank test was applied to assess variation within paired groups. In the case of TCRBV perturbations, comparisons were performed by two-way repeated measures ANOVA with treatment as one factor, and time as the other factor, after data transformation (inverse of the squared root). The association between nominal variables was assessed with the Chi-Square test with Yates' correction or with the Fisher test. The correlations between quantitative variables were tested by Pearson's coefficient and analyzed by simple linear regression. All p-values were corrected with the Bonferroni adjustment in case of multiple comparisons. The analyses were performed with Prism 5.0 software (GraphPad, San Diego, CA) and Stata Statistical Software Release 12 (StataCorp LP, College Station, TX).

\section{Results}

Phenotypic characterization of circulating T cells

The percentage and number of $\mathrm{CD} 4{ }^{+} \mathrm{CD} 28^{\text {neg }} \mathrm{T}$ cells did not differ between RA patients and $\mathrm{HC}$ before therapy initiation, but the median percentage of these cells was significantly reduced after 12 months of ABA (Table 2). The percentage of $\mathrm{CD} 44^{+} \mathrm{CD} 28^{\text {neg }} \mathrm{T}$ cells decreased in most patients, in some remained almost unchanged, and increased in 8 patients (Figure 1). Also $\mathrm{CD} 8^{+} \mathrm{CD} 28^{\text {neg }} \mathrm{T}$ cells, which were significantly higher in RA patients at $\mathrm{T} 0$, significantly decreased at $\mathrm{T} 12$. The reduction of $\mathrm{CD} 28^{\text {neg }}$ cell percentage in the $\mathrm{CD} 4^{+}$subset (Additional file 1: Figure $\mathrm{S} 1 \mathrm{~A}$ ), but not in the $\mathrm{CD}^{+}$counterpart, correlated with the decrease in disease activity, assessed by DAS28-CRP (r:0.43; p:0.045 and r:0.123; p:0.469).

The thymic output, measured by means of RTE levels, was similar to that of $\mathrm{HC}$ before ABA therapy, and the treatment did not significantly modify the proportion and absolute number of these cells. Similarly, the percentage and the absolute number of $\mathrm{CD} 4^{+} \mathrm{CD} 45 \mathrm{RA}^{+} \mathrm{CCR} 7^{-}$highly antigen-experienced $\mathrm{T}$ cells were not modified by the treatment.

\section{T-cell repertoire and TERT levels}

TCRBV repertoire was analyzed in a subgroup of $17 \mathrm{pa}-$ tients, enrolled starting from November 2009, in whom sufficient quality and quantity of biological material was available. The minor differences found between these 17 patients and the entire cohort of enrolled patients (Table 1) were likely due to the different use of ABA in clinical practice during time. In fact, initially reserved for patients resistant to other biological drugs, often after multiple therapy failures, ABA was progressively employed also as a second- or even first- line choice in disease modifying anti-rheumatic drug-resistant patients.

Before therapy initiation, the median proportion of TCRBV families with altered CDR3 (i.e. with shifted/ skewed, restricted or mono/oligoclonal distribution) was

Table 2 Variations of T-cell subpopulations after therapy with ABA and comparison with healthy controls

\begin{tabular}{|c|c|c|c|c|c|}
\hline & $\mathrm{HC}^{\mathrm{a}}$ & $\begin{array}{l}\mathrm{p} \\
\text { (HC vs. T0) }\end{array}$ & RA TO ${ }^{b}$ & RA T12 & $\begin{array}{l}\mathrm{p} \\
\text { (RA T0 vs. RA T12) }\end{array}$ \\
\hline $\mathrm{CD}^{+}{ }^{+} \mathrm{CD} 28^{\text {neg }}(\%)$ & $3.6(2.6-4.5)$ & 0.996 & $5.0(2.5-8.7)$ & $1.6(0.4-9.2)$ & 0.032 \\
\hline $\mathrm{CD} 4^{+} \mathrm{CD} 28^{\text {neg }}(\mathrm{cells} / \mu \mathrm{L})$ & $34(22-78)$ & 0.588 & $35(21-76)$ & $15(8-25)$ & 0.096 \\
\hline $\mathrm{CD} 8+\mathrm{CD} 28^{\text {neg }}(\%)$ & $14.6(7.3-23.1)$ & $<0.001$ & $39.4(25.6-50.4)$ & $27.8(14.8-35.6)$ & 0.012 \\
\hline $\mathrm{CD} 8^{+} \mathrm{CD} 28^{\text {neg }}(\mathrm{cells} / \mu \mathrm{L})$ & $53(28-117)$ & 0.072 & $96(58-148)$ & $44(30-95)$ & 0.006 \\
\hline $\mathrm{CD}^{+} \mathrm{CD} 45 \mathrm{RA}^{+} \mathrm{CD} 1^{+} \mathrm{RTE}^{\mathrm{d}}(\%)$ & $25.0(20.6-25.8)$ & 1.000 & $18.4(14-29.2)$ & $19.3(15.7-32.1)$ & 1.000 \\
\hline $\mathrm{CD}^{+} \mathrm{CD}^{2} 5 \mathrm{RA}^{+} \mathrm{CD} 1^{+}$RTE (cells $\left./ \mu \mathrm{L}\right)$ & $182(138-202)$ & 0.582 & $155(98-307)$ & $226(123-344)$ & 1.000 \\
\hline $\mathrm{CD}^{+} \mathrm{CD} 45 \mathrm{RA}^{+} \mathrm{CCR}^{-}(\%)$ & $0.9(0.4-1.6)$ & 0.164 & $2.1(0.5-5.1)$ & $0.9(0.6-1.9)$ & 0.076 \\
\hline 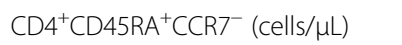 & $6(5-11)$ & 0.340 & $13(6-27)$ & $9(3-28)$ & 0.132 \\
\hline
\end{tabular}

Data are expressed as median and IQR.

${ }^{\mathrm{a}} \mathrm{HC}$ : healthy controls; ${ }^{\mathrm{b}} \mathrm{TO}$ : before $\mathrm{ABA}$ therapy; ${ }^{\mathrm{C}} \mathrm{T} 12$ : after 12 months of ABA therapy; ${ }^{\mathrm{d}} \mathrm{RTE}$ : recent T emigrants. 


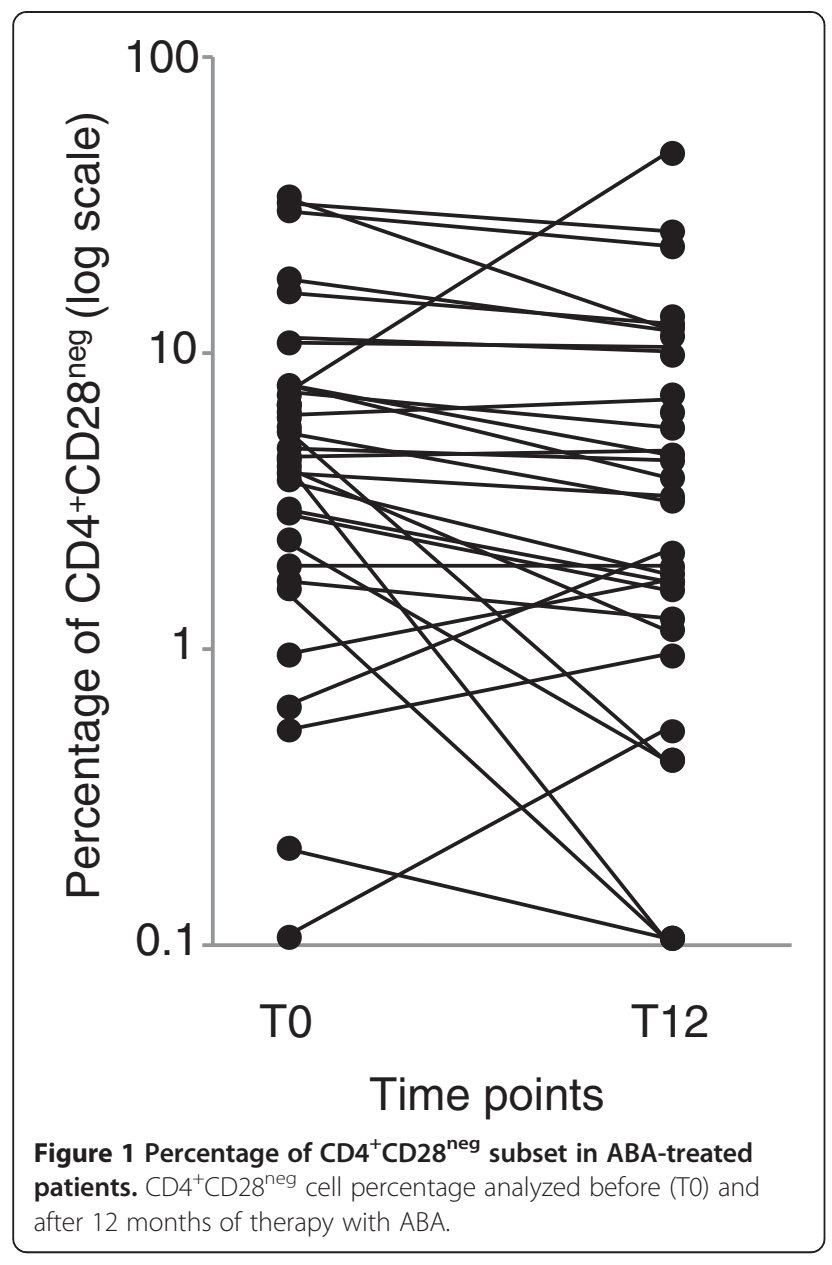

higher than in $\mathrm{HC}$ [78\% (68\%-85\%) vs. $52 \%$ (29-61\%); $\mathrm{p}<0.0001$ ] (Figure 2A), but significantly decreased after 12 months of treatment, [70\% (59-74\%); $\mathrm{p}=0.007]$. The same results were observed when the mean percentage of all TCRBV chain perturbations of all patients were globally analyzed (Figure 2B) and when TCRBV perturbations were analyzed in individual RA patient by calculating the difference between the alterations of CDR3 profiles observed at T12 and at T0 (Figure 2C). Indeed, perturbations decreased in most patients and in one of them (patient \#16), the reduction involved nearly all TCRBV chains. In this patient a modification of altered CDR3 profile was observed in 22 out the 23 TCRBV chains analyzed, that acquired a nearly Gaussian-like (polyclonal) distribution in the sample obtained at 12 months of ABA therapy (Figure 3).

The lowering of TCRBV chain perturbations correlated with the reduction of $\mathrm{CD} 4{ }^{+} \mathrm{CD} 28^{\text {neg }}$ subset percentage ( $r: 0.55$; p:0.026; Additional file 1: Figure S1B), but not with the changes of $\mathrm{CD} 8^{+} \mathrm{CD} 28^{\text {neg }}$ or RTE percentages. Analogously, the variations of TCRBV repertoire diversity after therapy with $A B A$ were not associated with age and disease duration, with the presence of rheumatoid factor, anti-cyclic citrullinated peptide antibodies, or with a decrease of disease activity as measured by the validated index DAS28-CRP.

The levels of TERT correlated with the average TCRBV perturbation at T0 $(\mathrm{r}: 0.72 ; \mathrm{p}=0.019)$, but no differences were found between samples obtained before and after ABA therapy [median NR: 66 (51-159) vs. 77 (32-183)].

\section{Discussion}

Herein we report that ABA treatment not only induces a decrease of the $\mathrm{CD} 28^{\text {neg }}$ cell subsets, but also causes a reduction of peripheral TCRBV oligoclonal cells that, stably present in RA patients over long periods of time, are considered of pathophysiologic relevance in this disease $[1,16]$.

The documented reduction of expanded clonotypes in our patients was not related to an immune reconstitution through a thymic output because newly produced $\mathrm{T}$ lymphocytes were equally represented before and after ABA therapy. This is in agreement with data indicating that ABA does not modify the level of interleukin-7 (IL-7), which is known to stimulate the thymic output [17]. A similar capacity to reduce clonal expansions of $\mathrm{CD}^{+} \mathrm{T}$ cells was observed by Pierer et al [18] in 19 RA patients treated with etanercept and in 9 with infliximab, two tumor-necrosis factor alpha (TNF $\alpha$ ) blocking agents.

The number of RTE was not directly evaluated by Pierer at al [18], but since anti-TNF $\alpha$ therapy increased the levels of IL-7, which is known to stimulate thymic output of $\mathrm{T}$ cells as well as the expansion of naïve peripheral $\mathrm{T}$ cells, the authors suggested that this might contribute to the normalization of the TCR repertoire. Of note, patient cells were phenotyped before anti-TNF $\alpha$ treatment initiation and after 2, 4 and 12 months by flow cytometry, but no significant changes in the percentage of $\mathrm{CD} 44^{+} \mathrm{CD} 28^{\text {neg }}$ population were found [18].

To understand why T-cell repertoire could broaden without a change in thymic production of $\mathrm{T}$ cells it must be taken into account that thymic output is necessary under lymphopenic conditions, when RTE can fill the void and restore the compromised TCR repertoire [19]. When this is not the case, as in our ABA-treated patients, newly produced $\mathrm{T}$ lymphocytes may be not accepted into the periphery [19] and, therefore, RTE may not be enriched in peripheral blood.

On the other hand, ABA-induced reduction of T-cell expansion was not due to the restoration of the defective telomerase activity that, demonstrated in naïve $\mathrm{T}$ cells of RA patients, can result into an excessive induction of apoptosis [11]. Indeed, an increased apoptosis may undermine the homeostatic control of the T-cell compartment and set the stage for lymphopenia-induced reduction of T-cell repertoire diversity. On the contrary, the correlation between TERT levels and the average 


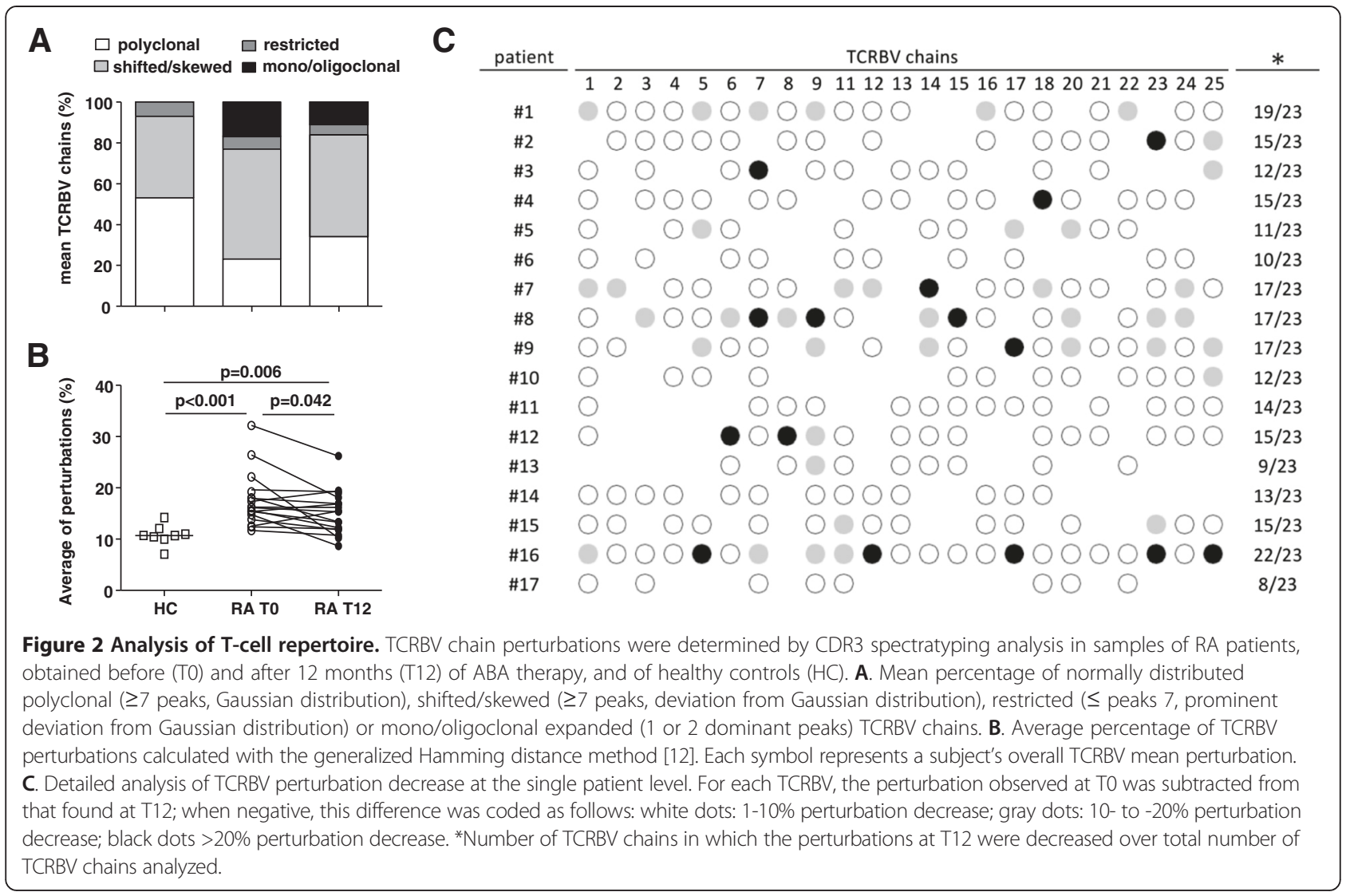

perturbations of TCRBV repertoire that we observed in samples obtained before ABA initiation, supports the hypothesis that high expression of telomerase coincides with periods of T-cell expansion [20,21]. The absence of TERT modifications after ABA therapy suggests that this is not a relevant factor in the repertoire broadening and other ways to reduce T-cell clonality may be operative. One such alternative scenario would be that $\mathrm{CD} 28^{\text {neg }}$ cells need regular TCR tuning for their survival and that ABA interferes with this and some clones thereby disappear.

We have not found a correlation between TCR repertoire modifications and disease activity variations, measured as DAS28-CRP index, making unlikely an indirect effect of reduced levels of inflammation on T-cell repertoire variations. Nevertheless, we cannot exclude a re-expression of CD28 on memory clonal T cells after ABA therapy; in this case variations on CD28-mediated trafficking of memory $\mathrm{T}$ cells [22] might contribute to the reduction of memory clonal populations in the peripheral blood.

The lack a control group such as RA patients treated with other drugs exerting a similar effect on $\mathrm{CD} 28^{\text {neg }}$ populations may be a limitation of the present study. However, it should be considered that, for instance, nonsteroidal anti-inflammatory drug, methotrexate and two TNF $\alpha$ blocking agents, have not effect on these cells $[18,23]$.

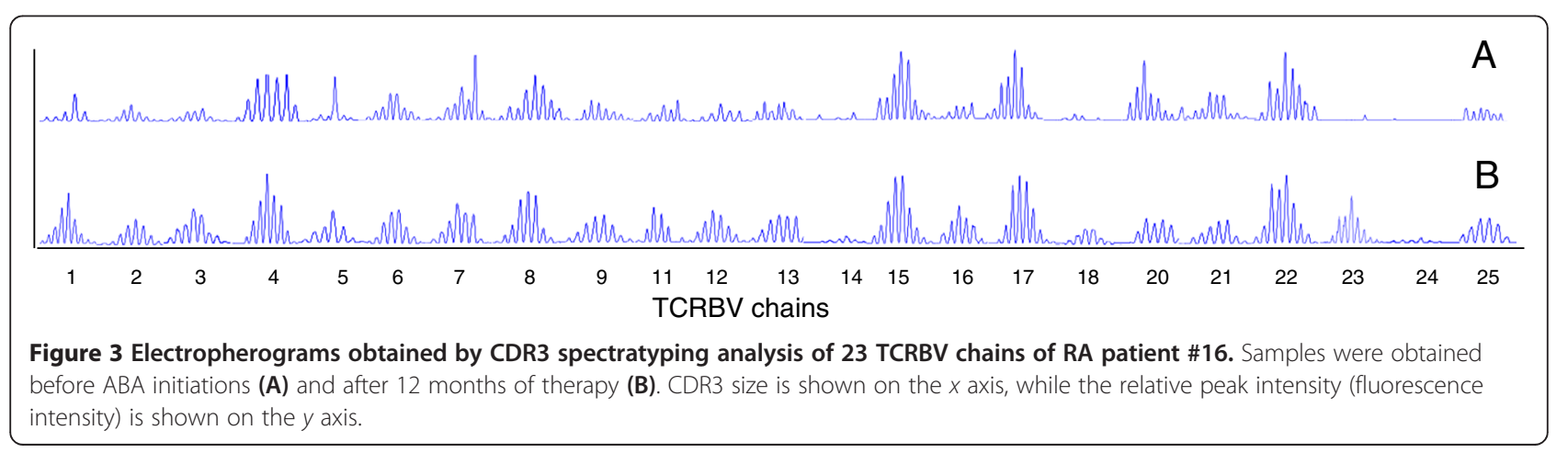




\section{Conclusions}

Our data suggest that blocking CD28-costimulation induces a reduction of peripheral blood T-cell expansions. The same results have been observed in patient treated with anti-TNF $\alpha$ [17], but the mechanism responsible for the normalization of T-cell expansion seem to be different. Indeed, in patients treated with $\mathrm{ABA}$, the correlation of the repertoire modifications with the reduction of the $\mathrm{CD} 4{ }^{+} \mathrm{CD} 28^{\text {neg }}$ population suggests that the diminished skewing of the repertoire is due to the decreased generation of these lymphocytes. This population consists mainly of senescent, highly antigen-experienced cells, largely overlapping with that displaying CD45RA ${ }^{+} \mathrm{CCR} 7^{-}$ phenotype. The proinflammatory properties of $\mathrm{CD} 4{ }^{+} \mathrm{CD} 28^{\text {neg }}$ cells (through $\gamma$-IFN production [23,24]), support their potential pathogenic role in $\mathrm{RA}$.

\section{Additional file}

Additional file 1: Figure S1. Correlation of variations of $C D 4^{+} C D 28^{\text {neg }}$ $T$ cell percentage after 12 months of $A B A$ treatment with variations of DAS28-CRP (A) and with the mean TCRVB perturbation rate (B).

\section{Abbreviations}

ABA: Abatacept; CDR3: Complementarity-determining region-3; DAS28-CRP: Disease Activity Score 28-C-reactive protein; HC: Healthy controls; RTE: Recent T emigrants; IQR: Interquartile range; RA: Rheumatoid arthritis; T0: Before abatacept therapy; T12: after 12 months of abatacept therapy; TCR: T-cell receptor; TCRBV: TCR variable beta; TERT: Telomerase reverse transcriptase.

\section{Competing interests}

Bristol-Myers-Squibb Italy provided an unrestricted research grant for the study conduct and did not interfere with the conception and design of the study, acquisition, analysis, interpretation of data, and manuscript drafting. The authors declare that they have no other competing interests.

\section{Authors' contributions}

LI: conceived of the study, participated in its design and coordination and draft the manuscript. MS and MC: carried out the phenotypic analysis and performed the statistical analysis; CZ and DB: performed the molecular analyses; AT: help in drafting the manuscript; PA: conceived of the study, participated in its design and coordination and helped to draft the manuscript. All authors read and approved the final manuscript.

\section{Acknowledgements}

The authors thank Bristol-Myers-Squibb Italy for the interest showed in this project and support

\section{Author details}

${ }^{1}$ Centro Ricerca Emato-oncologica AIL (CREA), Diagnostics Department, Spedali Civili of Brescia, p.le Spedali Civili di Brescia, 1, 25123 Brescia, Italy. ${ }^{2}$ Rheumatology and Clinical Immunology, Spedali Civili of Brescia, Brescia, Italy.

Received: 26 August 2014 Accepted: 15 December 2014

Published online: 16 January 2015

\section{References}

1. Schmidt D, Goronzy JJ, Weyand CM: CD4 + CD7-CD28-T cells are expanded in rheumatoid arthritis and are characterized by autoreactivity. J Clin Invest 1996, 97:2027-2037.
2. Vallejo AN, Brandes JC, Weyand CM, Goronzy JJ: Modulation of CD28 expression: distinct regulatory pathways during activation and replicative senescence. J Immunol 1999, 162:6572-6579.

3. Vallejo AN, Weyand CM, Goronzy JJ: T-cell senescence: a culprit of immune abnormalities in chronic inflammation and persistent infection. Trends Mol Med 2004, 10:119-124.

4. Broux B, Markovic-Plese $S$, Stinissen P, Hellings N: Pathogenic features of CD4 + CD28- T cells in immune disorders. Trends Mol Med 2012, 18:446-453.

5. Pawlik A, Ostanek L, Brzosko I, Brzosko M, Masiuk M, Machalinski B, Gawronska-Szklarz B: The expansion of CD4 + CD28- T cells in patients with rheumatoid arthritis. Arthritis Res Ther 2003, 5:R210-R213.

6. Cutolo M, Nadler SG: Advances in CTLA-4-lg-mediated modulation of inflammatory cell and immune response activation in rheumatoid arthritis. Autoimmun Rev 2013, 12:758-767.

7. Ndejembi MP, Teijaro JR, Patke DS, Bingaman AW, Chandok MR, Azimzadeh A Nadler SG, Farber DL: Control of memory CD4 T cell recall by the CD28/B7 costimulatory pathway. J Immunol 2006, 177:7698-7706.

8. Pieper J, Herrath J, Raghavan S, Muhammad K, Vollenhoven RV, Malmström V: CTLA4-lg (abatacept) therapy modulates T cell effector functions in autoantibody-positive rheumatoid arthritis patients. BMC Immunol 2013, $14: 34$

9. Scarsi M, Ziglioli T, Airo' P: Baseline numbers of circulating CD28-negative T cells may predict clinical response to abatacept in patients with rheumatoid arthritis. J Rheumato/ 2011, 38:2105-2111.

10. Airò P, Scarsi M: Targeting CD4 + CD28- T cells by blocking CD28 co-stimulation. Trends Mol Med 2013, 19:1-2.

11. Fujii H, Shao L, Colmegna I, Goronzy JJ, Weyand CM: Telomerase insufficiency in rheumatoid arthritis. Proc Natl Acad Sci U S A 2009, 106:4360-4365.

12. Wells G, Becker JC, Teng J, Dougados M, Schiff M, Smolen J, Aletaha D, van Riel PL: Validation of the 28-joint Disease Activity Score (DAS28) and European League Against Rheumatism response criteria based on C-reactive protein against disease progression in patients with rheumatoid arthritis, and comparison with the DAS28 based on erythrocyte sedimentation rate. Ann Rheum Dis 2009, 68:954-960.

13. Akatsuka Y, Martin EG, Madonik A, Barsoukov AA, Hansen JA: Rapid screening of T-cell receptor (TCR) variable gene usage by multiplex PCR: application for assessment of clonal composition. Tissue Antigens 1999, 53:122-134.

14. Gorochov G, Neumann AU, Kereveur A, Parizot C, Li T, Katlama C, Karmochkine M, Raguin G, Autran B, Debré P: Perturbation of CD4+ and CD8+ T-cell repertoires during progression to AIDS and regulation of the CD4+ repertoire during antiviral therapy. Nat Med 1998, 4:215-221.

15. Warnke C, Mausberg AK, Stettner M, Dehmel T, Nekrich L, Meyer zu Horste G, Hartung HP, Fogdell-Hahn A, Adams O, Kieseier BC: Natalizumab affects the T-cell receptor repertoire in patients with multiple sclerosis. Neurology 2013, 81:1400-1408.

16. Koetz K, Bryl E, Spickschen K, O'Fallon WM, Goronzy JJ, Weyand CM: T cell homeostasis in patients with rheumatoid arthritis. Proc Natl Acad Sci U S A 2000, 97:9203-9208.

17. Soares MV, Borthwick NJ, Maini MK, Janossy G, Salmon M, Akbar AN: IL-7-dependent extrathymic expansion of CD45RA+ T cells enables preservation of a naive repertoire. J Immunol 1998, 161:5909-5917.

18. Pierer M, Rossol M, Kaltenhäuser S, Arnold S, Häntzschel H, Baerwald C, Wagner U: Clonal expansions in selected TCR BV families of rheumatoid arthritis patients are reduced by treatment with the TNFa inhibitors etanercept and infliximab. Rheumatol Int 2011, 31:1023-1029.

19. Houston EG Jr, Higdon LE, Fink PJ: Recent thymic emigrants are preferentially incorporated only into the depleted T-cell pool. Proc Natl Acad Sci U S A 2011, 108:5366-5371.

20. Weng NP, Levine BL, June $\mathrm{CH}$, Hodes RJ: Regulated expression of telomerase activity in human T lymphocyte development and activation. J Exp Med 1996, 183:2471-2479.

21. Hodes RJ, Hathcock KS, Weng NP: Telomeres in T and B cells. Nat Rev Immunol 2002, 2:699-706.

22. Mirenda V, Jarmin SJ, David R, Dyson J, Scott D, Gu Y, Lechler RI, Okkenhaug K, Marelli-Berg FM: Physiologic and aberrant regulation of memory T-cell trafficking by the costimulatory molecule CD28. Blood 2007, 109:2968-2977. 
23. Fasth AE, Snir O, Johansson AA, Nordmark B, Rahbar A, Af Klint E, Björkström NK, Ulfgren AK, van Vollenhoven RF, Malmström V, Trollmo C: Skewed distribution of proinflammatory CD4 + CD28null T cells in rheumatoid arthritis. Arthritis Res Ther 2007, 9:R87.

24. Scarsi M, Zanotti C, Chiarini M, Imberti L, Piantoni S, Frassi M, Tincani A, Airò P: Reduction of peripheral blood $\gamma$-IFN and IL-17 producing T cells after therapy with abatacept for rheumatoid arthritis. Clin Exp Rheumatol 2014, 32:204-210

\section{Submit your next manuscript to BioMed Central} and take full advantage of:

- Convenient online submission

- Thorough peer review

- No space constraints or color figure charges

- Immediate publication on acceptance

- Inclusion in PubMed, CAS, Scopus and Google Scholar

- Research which is freely available for redistribution 